\title{
Późnoglacjalna i holoceńska ewolucja torfowiska w Dzikowie (Kotlina Toruńska) w świetle badań paleogeograficznych
}

\author{
Late glacial and holocene evolution of the Dzikowo peatland (Toruń Basin) based \\ on palaeogeographical analyses
}

\author{
Iwona Krześlak, Leon Andrzejewski, Wojciech Gamrat, Anna Kupniewska \\ Katedra Geomorfologii i Paleogeografii Czwartorzędu, Uniwersytet Mikołaja Kopernika, Toruń, krzeslak@doktorant.umk.pl
}

Zarys treści: Przedmiotem badań są osady wypełniające zagłębienie wytopiskowe w Dzikowie, we wschodniej części Kotliny Toruńskiej, około 20 km na południowy wschód od Torunia. Analizowane wytopisko oraz sąsiadujące z nim Jezioro Dzikowskie usytuowane są na terasie Wisły. W celu odtworzenia ewolucji środowiska przyrodniczego tego obszaru przeprowadzono badania multidyscyplinarne. Badania geologiczne pozwoliły na określenie maksymalnej miąższości osadów biogenicznych w obrębie analizowanego wytopiska na około $10 \mathrm{~m}$. Szczegółowe analizy paleoekologiczne (geochemiczne, palinologiczne i makroszczątków roślinnych) dostarczyły informacji o zmianach środowiska przyrodniczego w późnym glacjale i holocenie oraz umożliwiły wyodrębnienie kolejnych etapów rozwoju paleojeziora.

Słowa kluczowe: analizy paleogeograficzne, analiza pyłkowa, makroszczątki roślinne, paleojezioro, Kotlina Toruńska

\begin{abstract}
The object of current research is core of the bottom sediments of a kettle-hole at the Dzikowo site. Study area is located in the eastern part of the Torun Basin, in the area of the Vistula terrace, approximately $20 \mathrm{~km}$ southeast of Torun. In order to reconstruct the environmental history of this region, multidisciplinary research was carried out. Geological research allowed to determine the maximum thickness of biogenic sediments to approximately $10 \mathrm{~m}$. Detailed paleoecological analyses (palynological, plant macroremains, geochemical) provided information about environmental changes in the Late Glacial and the Holocene and helped to identify stages in the evolution of the paleolake basin.
\end{abstract}

Key words: paleogeographical analyses, palynology, plant macroremains, paleolake, Toruń Basin

\begin{abstract}
Wstęp
Osady organiczne wypełniające zagłębienia wytopiskowe w obrębie Kotliny Toruńskiej nie były dotychczas przedmiotem kompleksowego opracowania paleogeograficznego. Jedne z pierwszych tego typu badań przeprowadziła Tomczak (1987), dokonując szczegółowej analizy osadów biogenicznych wypełniających zagłębienie wytopiskowe oddalone o około $1 \mathrm{~km}$ na północny zachód od prezentowanego w niniejszym artykule. Wówczas badaniom palinologicznym poddano rdzeń osadów jeziorno-torfowiskowych o miąższości ponad $7 \mathrm{~m}$. Badania realizowane na stanowisku Dzikowo nawiązują do ww. i zdaniem autorów przyczynią się do pełniejszego poznania ewolucji
\end{abstract}

środowiska geograficznego wschodniej części Kotliny Toruńskiej w późnym glacjale i holocenie. W oparciu o ich pierwsze wyniki możliwe stało się określenie sukcesji roślinności i zmian klimatycznych na tym obszarze oraz odtworzenie etapów ewolucji analizowanego paleojeziora. Będą one pomocne także w ustaleniu chronostratygrafii zdarzeń geomorfologicznych w tej części doliny Wisły.

\section{Obszar badań}

Obszar badań zlokalizowany jest we wschodniej części mezoregionu Kotlina Toruńska (Kondracki 1998), około $20 \mathrm{~km}$ na południowy wschód od Torunia w miejscowości 


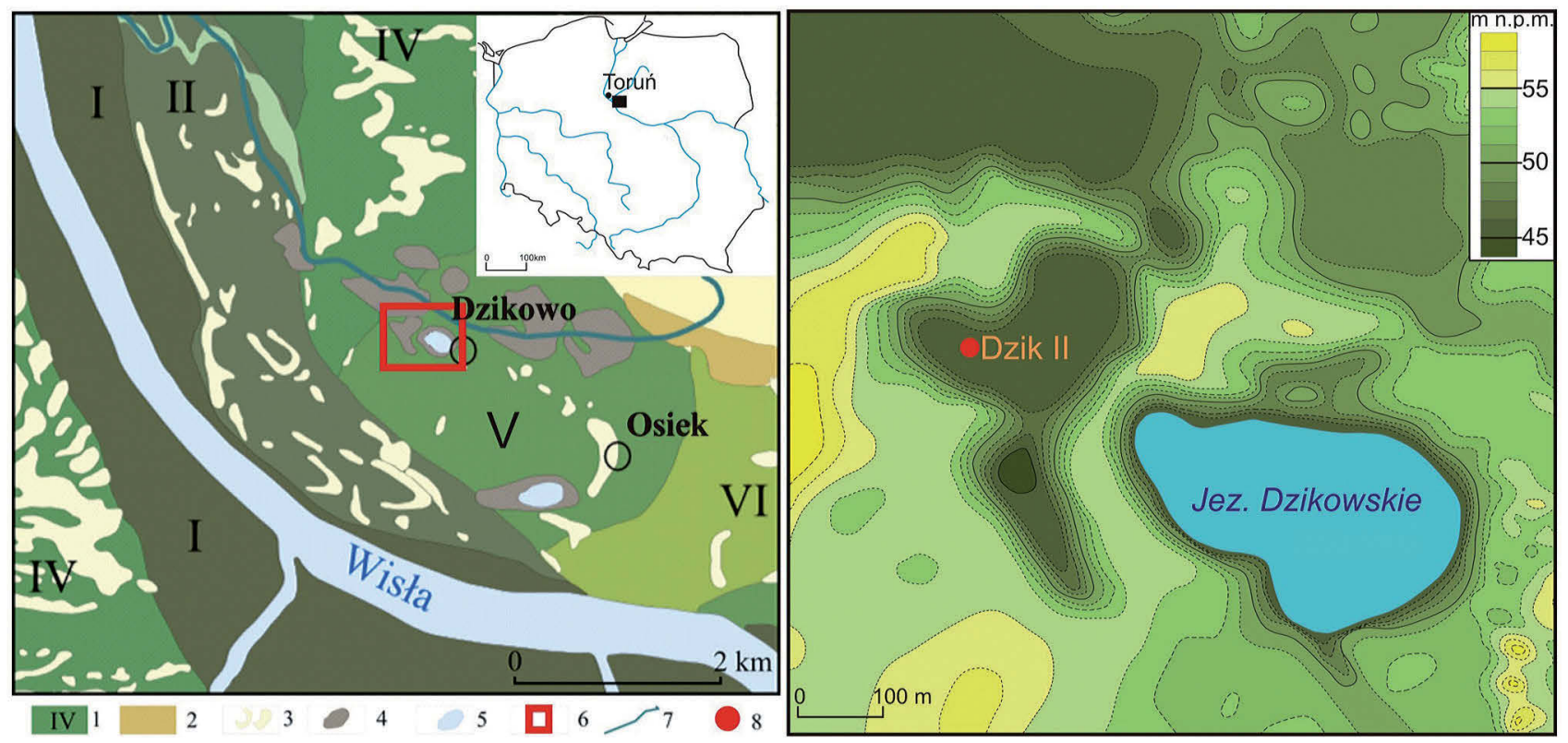

Ryc. 1. Lokalizacja obszaru badań na tle teras Wisły (Niewiarowski, Weckwerth 2006 - zmodyfikowane)

1 - terasy Wisły, 2 - erozyjne równiny wód roztopowych, 3 - wydmy, 4 - zagłębienia wytopiskowe, 5 - jeziora, 6 - stanowisko badań, 7 - cieki, 8 miejsce poboru rdzenia Dzik II

Fig. 1. Location of the study area on the background of the Torun Basin (Niewiarowski, Weckwerth $2006-$ modified)

1 -Vistula terraces, 2 - meltwater erosional plains, 3 - dunes, 4 - kettles, 5 - lakes, 6 - research site, 7 - watercourse, 8 - place of Dzik II coring

Dzikowo (ryc. 1). Obejmuje on torfowisko niskie położone w bezpośrednim sąsiedztwie Jeziora Dzikowskiego. Osady biogeniczne wypełniają tu dno niewielkiego, bezodpływowego zagłębienia wytopiskowego usytuowanego na wysokości około 46 m n.p.m. w obrębie V terasy Wisły. Maksymalna miąższość osadów w obniżeniu przekracza $10 \mathrm{~m}$.

\section{Metody badań}

Kartowanie terenowe poprzedziły szczegółowe studia literatury i materiałów geologicznych, geomorfologicznych, hydrologicznych i klimatycznych dotyczących obszaru badań.

W terenie sondą Livingstone'a w modyfikacji Więckowskiego (Więckowski 1989) pobrano z północnej części torfowiska trzy rdzenie osadów jeziornych i torfowiskowych o nienaruszonej strukturze. Dotychczas szczegółowo opracowano rdzeń Dzik II, prezentowany w niniejszym artykule (ryc. 2). Dodatkowo świdrem ręcznym typu Ejikelkamp wykonano szereg sondowań geologicznych celem rozpoznania miąższości i charakteru osadów biogenicznych wypełniających misę badanego zagłębienia wytopiskowego. Podczas prac terenowych stwierdzono, szczególnie w południowej części torfowiska, obecność śladów działalności człowieka, tj. melioracje i nasadzenia młodych drzew.

Osady rdzenia Dzik II były przedmiotem badań laboratoryjnych, w ramach których wykonano wybrane analizy geochemiczne i paleoekologiczne. Badania geochemiczne osadów objęły: pomiary $\mathrm{pH}$, zawartości krzemionki terygenicznej, analizę strat prażenia Bengstonne'a-Ennela
(1986) oraz zawartości węglanów. W ramach badań paleobotanicznych wykonano analizę pyłkową oraz analizę makroszczątków roślinnych. Prace laboratoryjne przeprowadzono według ogólnie przyjętych norm i wytycznych (Tobolski 2000, Sadowska, Chłopek 2003, Velichkevich, Zastawniak 2006, Hulisz i in. 2012). Wynikowe diagramy wykonano w programie PolPal (Walanus, Nalepka 1996).

\section{Wyniki badań}

\section{Analizy geochemiczne}

W pobranym rdzeniu występują zarówno osady jeziorne, jak i torfowiskowe (ryc. 2). W jego spągu, na utworach piaszczystych stanowiących mineralne podłoże misy jeziornej, zalegają węglanowe osady jeziorne. Reprezentowane są one przez gytię ilasto-wapienną oraz gytię wapienną. Wyraźnie zaznacza się większy udział substancji mineralnej (do ok. 49\%) w porównaniu do osadów nadległych. Powyżej głębokości $555 \mathrm{~cm}$ zmniejsza się znacznie udział substancji mineralnej na korzyść węglanów i materii organicznej. Osad przybiera postać gytii wapiennej z wyraźnie zaznaczającym się warstwowaniem. Maksymalny udział związków węglanowych przekracza miejscami $85 \%$, co według klasyfikacji Markowskiego (Markowski 1980) pozwala zaklasyfikować osad jako kredę jeziorną. Na głębokości 345-330 cm stwierdzono warstwę czarnej gytii organicznej, początkowo drobno-, a następnie grubodetrytusowej, w której udział materii organicznej sięga do około 76\%. Stropową część profilu stanowi stosunkowo jednolity torf. Początkowo ma on charakter mszysty, stop- 
niowo przechodzący w trzcinowy. Udział materii organicznej osiąga w tej części profilu wartość około 90\%, z wyjątkiem warstwy powierzchniowej, w której zaznaczył się proces murszenia, czego dowodem jest zwiększony udział substancji mineralnej, tj. do około $47 \%$.

Wartości pH w całym profilu wahają się od 6,20 do 7,84. Najniższe pH zmierzono w osadach spągu (gytia) na głębokości $620 \mathrm{~cm}$, zaś najwyższe na głębokości 345 cm (gytia). Wyraźna zmiana odczynu następuje na granicy litologicznej między gytią a torfem. Utwory limniczne mają odczyn lekko zasadowy, co wiąże się z wysoką zawartością węglanów. Z kolei zasobne w materię organiczną i ubogie w węglany osady torfowe wykazują odczyn lekko kwaśny. Wyjątkiem są osady stropu profilu (0-80 $\mathrm{cm})$, gdzie pH przyjmuje wartości powyżej 7.

Analizę zawartości krzemionki terygenicznej w całej próbce wykonano jedynie dla spągowej części profilu. Składnik ten wykazywał zróżnicowaną wartość, jednak wyraźnie zaznacza się jego gwałtowny spadek pokrywa- jący się z granicą między późnym glacjałem a holocenem $(555 \mathrm{~cm})$.

Utwory limniczne wydzielono na podstawie podziału Markowskiego (Markowski 1980), z kolei torfowe w oparciu o wyniki ekspertyzy makroszczątków roślinnych. Strukturę osadów rdzenia Dzik II oraz wyniki analiz geochemicznych zaprezentowano na rycinie 2 .

\section{Analiza palinologiczna}

Szczegółowej analizie poddano 65 próbek o objętości $1 \mathrm{~cm}^{3}$. Wyniki analizy pyłkowej wykonanej dla osadów profilu Dzik II przedstawiono w formie syntetycznego opisu (tab. 1). Z uwagi na prowadzone dalsze badania na stanowisku Dzikowo opis ten zawiera wstępny podział chronostratygraficzny, który oparty został na zmiennym udziale taksonów drzew i krzewów (AP) oraz wybranych roślin zielnych (NAP). Podział ten naniesiono również na końcowy fragment diagramu pyłkowego (ryc. 3).
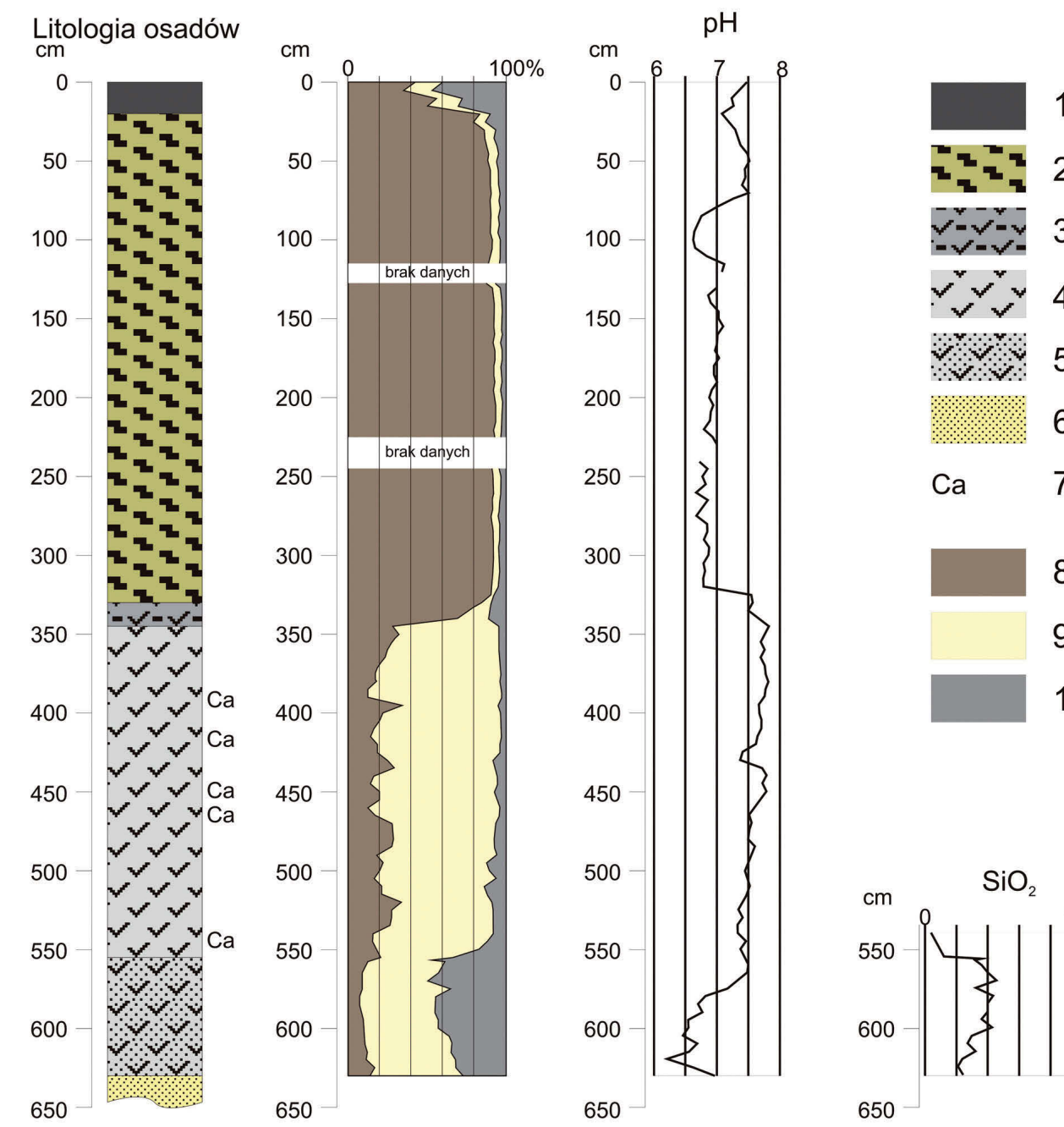

Ca 7
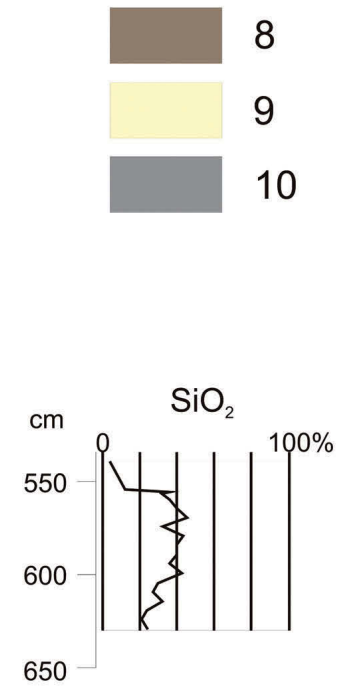

Ryc. 2. Charakterystyka osadów rdzenia Dzik II oraz wyniki analiz geochemicznych

1 - humotorf, 2 - torf trzcinowy i mszysto-trzcinowy, 3 - gytia detrytusowa, 4 - gytia węglanowa, 5 - gytia ilasto-wapienna, 6 - piasek, 7 - miejsca wzbogacone w węglan wapnia, 8 - materia organiczna, 9 - węglany, 10 - substancja mineralna

Fig. 2. Sediments of Dzik II core and results of geochemical analyses

1 - humopeat, 2 - reed and moos peat, 3 - detritus gyttja, 4 - calcerous gyttja, 5 - clay-calcerous gyttja, 6 - sand, 7 - hight content of calcium carbonate, 8 - organic matter, 9 - carbonates, 10 - mineral matter 


\section{Analiza makroszczątków roślinnych}

Analizie makroszczątków roślinnych poddano 59 próbek o porównywalnej objętości (ok. $30 \mathrm{ml}$ ) pobranych z rozdzielczością 10-centymetrową. Uzyskane wyniki obrazują ewolucję szaty roślinnej torfowiska i jego najbliższego otoczenia. Rezultaty analizy przedstawiono w formie histogramu (ryc. 4), w którego obrębie wydzielono poziomy charakteryzujące poszczególne stadia rozwoju zbiornika. Poziomy wyznaczone zostały na podstawie występowania taksonów dominujących lub charakterystycznych. Syntetyczny opis poziomów przedstawiono w formie tabeli (tab. 2).

\section{Rekonstrukcja zmian środowiska przyrodniczego torfowiska w Dzikowie i jego najbliższego otoczenia}

Wyniki analizy palinologicznej wykazały, że akumulacja osadów organicznych w zagłębieniu rozpoczęła się w czasie obecności zbiorowisk leśnych zdominowanych przez sosnę zwyczajną (Pinus sylvestris) z domieszką brzozy (Betula), w tym brzozy karłowatej (Betula nana). Udział roślinności zielnej, reprezentowanej głównie przez trawy (Poaceae), był wówczas niewielki (poniżej 10\%). Wyniki te sugerują, że sedymentacja osadów w spągu profilu rozpoczęła się w młodszej części allerødu (faza sosnowa), w warunkach umiarkowanego klimatu z cechami kontynentalizmu (Ralska-Jasiewiczowa 1966, Lindner 1992b,

Tabela 1. Syntetyczny opis wyników analizy pyłkowej profilu Dzik II

Table 1. Results of palynology analysis from Dzik II core

\begin{tabular}{ccc}
\hline $\begin{array}{c}\text { Głębokość } \\
{[\mathrm{cm}]}\end{array}$ & $\begin{array}{c}\text { Podział biostratygraficzny } \\
\text { (Mangerud i in. 1974) }\end{array}$ & Opis poziomów pyłkowych \\
\hline $630-615$ & Alleröd & Wśród drzew i krzewów (AP) dominuje sosna (Pinus sylvestris) - około 75\%, ze znacz-
\end{tabular}

630-615 Alleröd Wśród drzew i krzewów (AP) dominuje sosna (Pinus sylvestris) - około 75\%, ze znacznym udziałem ziaren pyłku brzozy (Betula) - około 15\% - oraz brzozy karłowatej (Betula nana), wierzby (Salix) i jałowca (Juniperus). Suma roślinności zielnej (NAP) nie przekracza 10\%; najwyższy udział wykazuje takson traw (Poaceae), turzycowatych (Cyperaceae) i bylic (Artemisia). Obecne są pojedyncze sporomorfy komosowatych (Chenopodiaceae) i różowatych (Rosaceae).

615-555 Młodszy dryas Obecne są absolutne maksima krzewiastych taksonów światłożądnych, tj. jałowca - maks. 9,67\% (średnio 4,06\%) - i brzozy karłowatej - maks. 7,14\% (średnio 4,47\%) - oraz wierzby - maks. $1,46 \%$ (średnio $0,82 \%$ ). Krzywa sosny notuje spadek przy jednoczesnym wzroście brzozy. Występowanie pojedynczych ziaren pyłku bardziej wymagających drzew i krzewów, tj. dębu (Quercus), lipy (Tilia) i olszy (Alnus), wskazuje na redepozycję części pyłku. Wysoki udział roślin zielnych (NAP) - około 20\%, wśród których dominują taksony: traw, bylic - absolutne maksimum 5,32\%, turzycowatych i komosowatych. Obecne są również ziarna pyłku posłonków (Helianthemum), dębika ośmiopłatkowego (Dryas octopetala) oraz pojedynczo babki (Plantago), szczawiu (Rumex) i różowatych.

555-495 Okres preborealny Wśród AP wymiennie dominują sosna zwyczajna i brzoza - absolutne maksimum 49,5\%. Pojawia się stała wiązu (Ulmus), leszczyny (Corylus) i dębu. Zanika krzywa jałowca oraz brzozy karłowatej. Wśród roślin zielnych najwyższy udział mają trawy, turzycowate i bylice. Obecne są także pojedyncze ziarna pyłku babki, szczawiu oraz różowatych.

495-345 Okres borealny Wśród drzew i krzewów zaznacza się wzrost krzywej sosny powyżej 80\%, stały udział leszczyny (średnio 3,9\%), wiązu (średnio 0,67\%) i dębu (średnio 0,97\%). Pojawia się stała krzywa olszy, a także ziarna pyłku lipy i jesionu (Fraxinus). Udział NAP wynosi kilka procent, początkowo (do głębokości $420 \mathrm{~cm}$ ), osiągając średnią powyżej $6 \%$, następnie zmniejsza się do średniej wartości około 4\%. Przyczyną wahań jest zmienny udział traw (takson dominujący, z absolutnym maksimum 9,47\%). Dodatkowo zaznacza się występowanie ciągłej krzywej turzycowatych oraz lokalnych krzywych bylic, rumianu (Anthemis), astrów (Aster), pokrzywy (Urtica) i taksonu konopii/chmielu (Cannabis/Humulus).

345-275 Okres atlantycki

$275-135$

Okres subborealny/ Okres subatlantycki
Poziom charakteryzuje się wysokim udziałem dębu (średnio 4,67\%), wiązu (średnio 2,1\%), leszczyny (średnio 8,38\%) i olszy (średnio 7,81\%). Swoje krzywe zaznaczają również lipa, jesion i świerk (Picea). Średnio udział roślin zielnych wynosi około 4\%, w którym największe krzywe mają trawy, turzycowate, wrzosowate (Ericaceae) i bylice.

Wśród drzew i krzewów notuje się wysoki udział leszczyny (średnio 5,5\%), dębu (średnio $4,21 \%$ ) oraz lipy (średnio 0,81\%) i olszy (średnio 5,45\%). Obecne są również nieciągłe krzywe wiązu, jesionu i świerka. Udział NAP, początkowo bardzo wysoki - ponad 20\%, zmniejsza się następnie poniżej 10\%. Dominującym taksonem są turzycowate, z niewielkim udziałem traw.

Wśród AP pojawia się stała krzywa graba (Carpinus), swój udział nieznacznie zwiększa olsza, dąb i leszczyna. Następuje niewielkie zmniejszenie udziału sosny, przy niskim udziale brzozy. Udział roślin zielnych wynosi kilka procent, zwiększając swoją krzywą pod koniec poziomu do $10 \%$. Zaznacza się stały udział turzycowatych oraz obecność ziaren traw, bylic, rumianu, astrów, szczawi, pokrzywy i zbóż (Cerealia). 


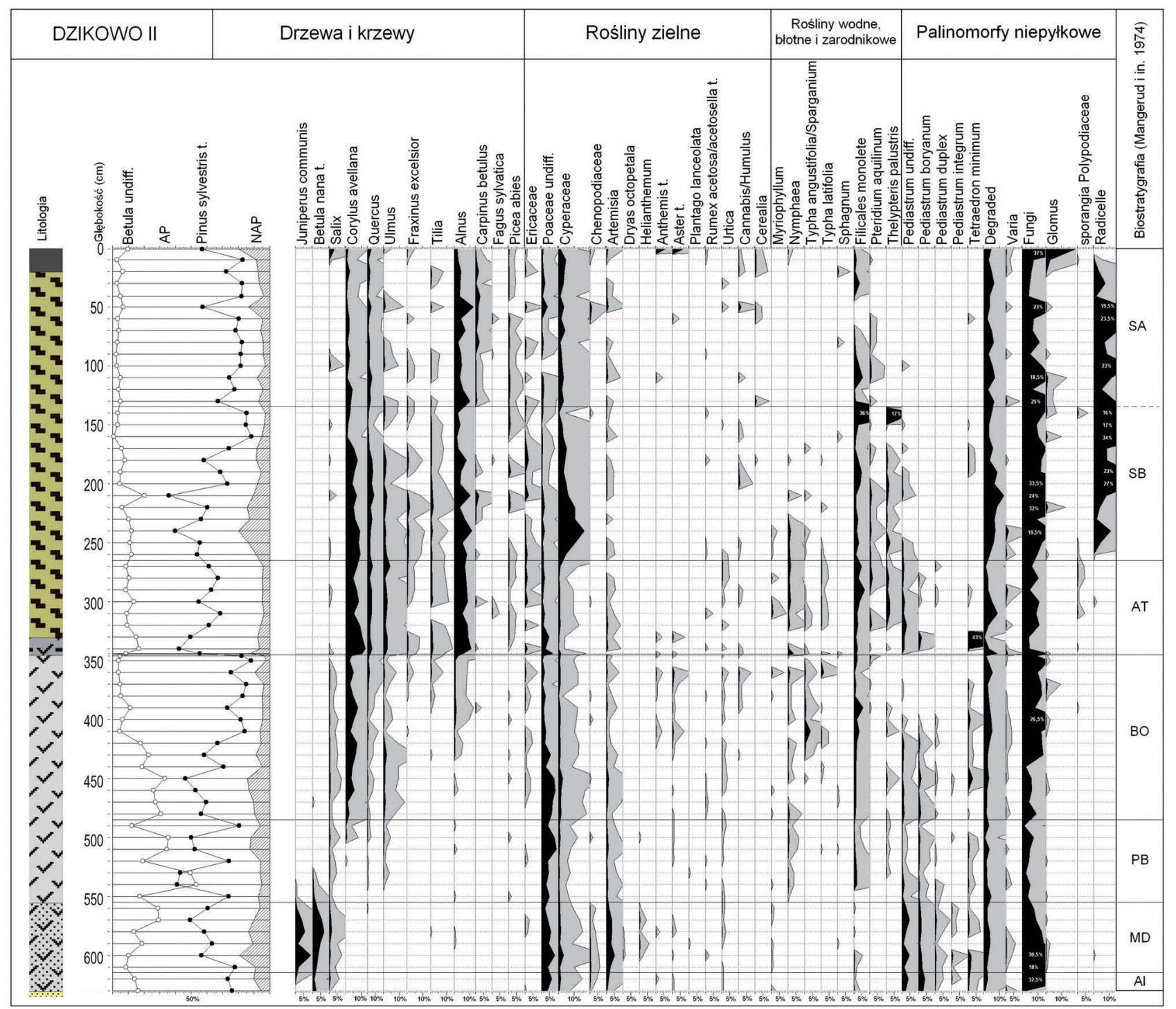

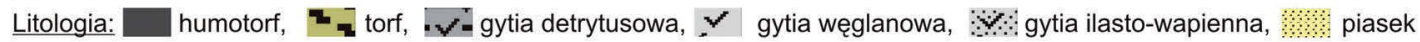

Ryc. 3. Diagram palinologiczny profilu Dzik II

Fig. 3. Pollen diagram from Dzik II core

Latałowa 2003). W jeziorze trwała wówczas akumulacja zasobnej w węglany i części mineralne gytii wapiennej. Podobną sytuację odzwierciedla zapis pyłkowy spągowego fragmentu rdzenia osadów z zagłębienia położonego około $1 \mathrm{~km}$ na północny zachód od badanego torfowiska (Tomczak 1987). Występujące tam spektra pyłkowe również dokumentują allerødzki wiek osadów organicznych.

W okresie młodszego dryasu nastąpiło wyraźne ochłodzenie klimatu, w wyniku czego w krajobrazie obok zbiorowisk leśnych pojawiły się step i lasotundra (Latałowa 2003). W zapisie pyłkowym osadów rdzenia Dzik II zmiany szaty roślinnej wyraziły się gwałtownym wzrostem ilości pyłku roślin zielnych (NAP) do około $20 \%$ na głębokości od 615 do $590 \mathrm{~cm}$. Obecność wśród nich gatunków światłożądnych, m.in. dębika ośmiopłatkowego (Dryas octopetala), bylic (Artemisia), komosowatych (Chenopodiaceae) i posłonków (Helianthemum) może świadczyć o rozrzedzeniu drzewostanów (Kupryjanowicz, Jurochnik 2009). Jednocześnie drzewostany sosnowe zostały zastą- pione przez gatunki krzewiaste, tj. brzozę karłowatą, jałowiec (Juniperus communis) oraz wierzbę (Salix).

W tym okresie w zbiorniku miała miejsce sedymentacja gytii, najpierw wapiennej, później ilasto-wapiennej, o nieco większym udziale substancji mineralnej. Była ona związana $\mathrm{z}$ nasileniem procesów erozyjno-denudacyjnych w obrębie zlewni zbiornika, co potwierdzać mogą znaleziska grzybów Cenococcum geophilum oraz wysoki udział krzemionki terygenicznej. Brak makroszczątków roślinnych w osadzie pozwala przypuszczać, że jezioro, będące wówczas w początkowej fazie rozwoju, było ubogie w roślinność i charakteryzowało się niską trofią.

Ocieplenie na granicy między późnym glacjałem i holocenem zaznacza się wyraźnie w obrazie roślinności otaczającej badane zagłębienie. Zanikły rośliny zimnolubne oraz światłolubne, a drzewostany uległy zagęszczeniu. Pojawiło się również wiele gatunków roślin związanych z lepszymi warunkami termicznymi i większym zacienieniem (Lindner 1992a). Zmiany klimatyczne u progu 


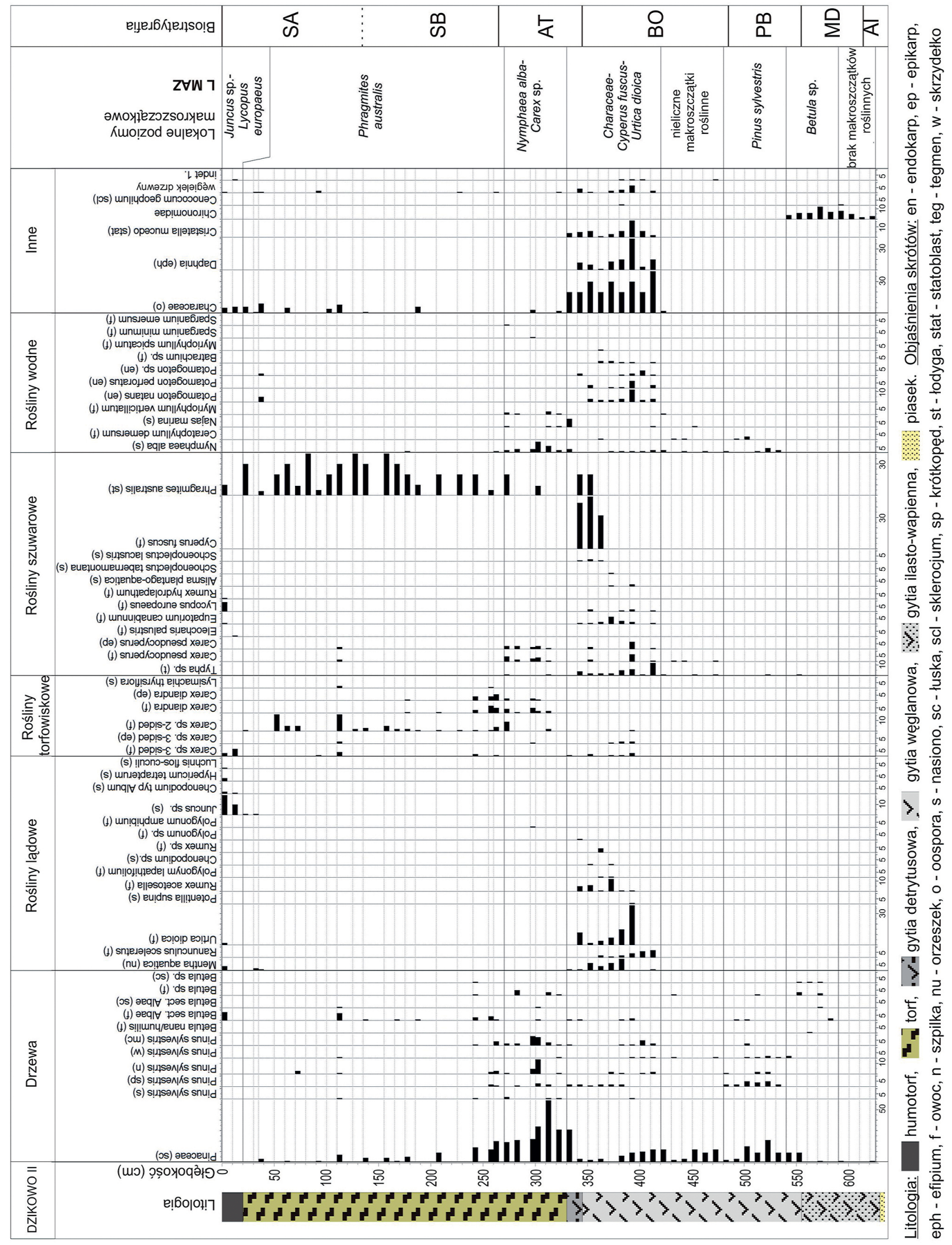


Tabela 2. Syntetyczny opis wyników analizy makroszczątków roślinnych profilu Dzik II

Table 2. Results of plant macrofossil analysis from Dzik II core

\begin{tabular}{|c|c|c|}
\hline $\begin{array}{l}\text { Głębokość } \\
{[\mathrm{cm}]}\end{array}$ & L MAZ & Opis poziomów makroszczątkowych \\
\hline $590-630$ & $\begin{array}{l}\text { brak makroszczątków } \\
\text { roślinnych }\end{array}$ & $\begin{array}{l}\text { Pierwszy poziom cechuje się zupełnym brakiem szczątków roślinnych. Rozpoznano jedy- } \\
\text { nie stosunkowo licznie występujące szczątki ochotkowatych (Chironomidae). }\end{array}$ \\
\hline $540-590$ & Betula sp. & $\begin{array}{l}\text { Poziom zdominowany przez subfosylne orzeszki i łuski brzozy (Betula sp.), w tym brzozy } \\
\text { karłowatej (Betula nana). Pojawiają się również pierwsze szczątki roślinności wodno-szu- } \\
\text { warowej (Typha sp.). }\end{array}$ \\
\hline $480-540$ & Pinus sylvestris & $\begin{array}{l}\text { Zaznacza się spadek liczby fosyliów brzozy na korzyść sosny zwyczajnej (Pinus sylve- } \\
\text { stris) reprezentowanych m.in. przez nasiona ze skrzydełkami, szpilki i krótkopędy. Coraz } \\
\text { liczniej pojawiają się również szczątki pierwszych makrofitów: grzybienia białego (Nym- } \\
\text { phaea alba) i rogatka sztywnego (Ceratophyllum demersum). }\end{array}$ \\
\hline $420-480$ & $\begin{array}{l}\text { nieliczne makroszczątki } \\
\text { roślinne }\end{array}$ & $\begin{array}{l}\text { Poziom cechuje się niewielką liczbą zachowanych w nim szczątków roślinnych. Wśród } \\
\text { fosyliów taksonów wodnych dominuje grzybień biały. Obecne są także szczątki rogatka } \\
\text { sztywnego oraz wywłócznika okółkowego (Myriophyllum verticillatum). Z grupy roślin- } \\
\text { ności szuwarowej znaleziono szczątki pałki wodnej oraz turzycy nibyciborowatej (Carex } \\
\text { pseudocyperus). }\end{array}$ \\
\hline $330-420$ & $\begin{array}{l}\text { Characeae-Cyperus } \\
\text { fuscus - Urtica dioica }\end{array}$ & $\begin{array}{l}\text { Wysoka liczebność szczątków roślin charakterystycznych dla wszystkich rodzajów } \\
\text { siedlisk. Spośród szczątków roślin wodnych dominują endokarpy rdestnic (Potamogeton } \\
\text { sp.), nasiona grzybienia białego i owoce włosiecznika (Batrachium sp.), a także oospory } \\
\text { ramienic (Characeae). Zaznacza się duży udział roślinności szuwarowej reprezentowanej } \\
\text { głównie przez ciborę brunatną (Cyperus fuscus) oraz w mniejszym stopniu przez pałkę } \\
\text { wodną, sadźca konopiastego (Eupatorium cannabinum), karbieńca pospolitego (Lycopus } \\
\text { europaeus) i oczeret jeziorny (Schoenoplectus lacustris). W pasie roślinności torfowisko- } \\
\text { wej występuje jedynie turzyca (Carex sp.). Zaznacza się natomiast wysoki udział fosyliów } \\
\text { flory lądowej. Zidentyfikowano liczne szczątki pokrzywy zwyczajnej (Urtica dioica), } \\
\text { mięty nadwodnej (Mentha aquatica), jaskra jadowitego (Rununculus sceleratus) oraz } \\
\text { szczawiu (Rumex sp.), w tym szczawiu polnego (Rumex acetosella). Znaleziono również } \\
\text { szczątki sosny. Wyodrębniono także dużą ilość fosyliów pochodzenia zwierzęcego, tj. efi- } \\
\text { pia rozwielitek (Daphnia) i statoblasty Cristatella mucedo. Pojawia się sklerocjum grzyba } \\
\text { Cenococcum geophilum oraz węgielek drzewny. Górna granica poziomu zaznacza się } \\
\text { bardzo wyraźnie zanikiem wielu taksonów, m.in. cibory brunatnej, pokrzywy zwyczajnej, } \\
\text { mięty nadwodnej, szczawiu oraz ramienic i rozwielitek. }\end{array}$ \\
\hline $270-330$ & $\begin{array}{l}\text { Nymphaea alba } \\
\text { - Carex sp. }\end{array}$ & $\begin{array}{l}\text { Poziom charakteryzuje się zanikiem szczątków roślin wodnych. Stosunkowo licznie } \\
\text { występują jeszcze nasiona grzybienia białego, jezierzy morskiej (Najas marina) oraz } \\
\text { wywłócznika kłosowego. W górnej części poziomu zaznacza się bardzo duży udział } \\
\text { trzciny pospolitej (Phragmites australis). Licznie reprezentowana jest także roślinność } \\
\text { torfowiskowa, głównie przez owoce turzyc. W poziomie zaznacza się wysoka liczebność } \\
\text { szczątków drzew, przede wszystkim sosny. Zidentyfikowano również orzeszki i łuski } \\
\text { brzozy drzewiastej (Betula sect. Albae). W stropowej części zaobserwowano obecność } \\
\text { węgielków drzewnych. }\end{array}$ \\
\hline $20-270$ & Phragmites & $\begin{array}{l}\text { W osadzie nie pojawiają się szczątki roślin wodnych. Licznie reprezentowana jest nato- } \\
\text { miast strefa szuwaru, o czym świadczą obficie występujące szczątki trzciny pospolitej } \\
\text { oraz owoce turzyc. Znacznie zmniejsza się udział fosyliów drzew. Zidentyfikowano także } \\
\text { pojedyncze węgielki drzewne. }\end{array}$ \\
\hline $0-20$ & $\begin{array}{l}\text { Juncus sp. - Lycopus } \\
\text { europaeus }\end{array}$ & $\begin{array}{l}\text { Brak szczątków flory wodnej. Licznie występują fosylia roślin szuwarowych i torfo- } \\
\text { wiskowych reprezentowanych głównie przez trzcinę pospolitą i karbieńca pospolitego. } \\
\text { Wyodrębniono także pojedyncze szczątki sadźca konopiastego. Liczne fosylia roślin } \\
\text { lądowych, pośród których dominuje sit (Juncus sp.). Pojawiają się również szczątki mięty } \\
\text { nadwodnej, dziurawca skrzydełkowatego (Hypericum tetrapterum), komosy (Chenopo- } \\
\text { dium sp.) oraz szczawiu. Zidentyfikowano orzeszki brzozy drzewiastej. Znaczny jest też } \\
\text { udział oospor ramienic. }\end{array}$ \\
\hline
\end{tabular}

holocenu wpłynęły też na charakter i strukturę osadów akumulowanych w samym zbiorniku. W wyniku intensywnego ługowania osadów polodowcowych w warunkach ocieplającego się klimatu gytia uległa znacznemu wzbogaceniu w węglany (ok. 65\%) oraz w mniejszym stopniu w materię organiczną (Latałowa 2003).

Postępująca poprawa warunków klimatycznych we wczesnym holocenie skutkowała wyraźnie bogatszą sza- tą roślinną w otoczeniu jeziora. Dominujące początkowo pionierskie lasy ze zmienną przewagą sosny i brzozy zaczęły się wzbogacać o gatunki bardziej wymagających drzew i krzewów, m.in. wiązu (Ulmus), dębu (Quercus), leszczyny (Corylus) oraz olszy (Alnus). Wyraźnie zmniejszył się wówczas udział roślinności zielnej $(<10 \%)$. Ewolucja szaty roślinnej na tym obszarze w okresie preborealnym i borealnym była typowa dla Polski północ- 
no-wschodniej. Znaczący był również rozwój roślinności w samym zbiorniku. W połowie okresu preborealnego pojawiły się pierwsze makroszczątki roślin wodnych (Nymphaea alba) i szuwarowych (Typha latifolia). Taksony te charakterystyczne są dla płytszych, wodno-szuwarowych stref zbiorników (Podbielkowski, Tomaszewicz 1996). W okresie borealnym w litoralu pojawiły się kolejne makrofity - jezierza morska (Najas marina) i wywłócznik okółkowy (Myriophyllum verticilatum), natomiast w najgłębszych partiach jeziora rogatek sztywny (Ceratophyllum demersum). Obecność tych taksonów świadczy o większej trofii wód.

U schyłku boreału zagłębienie cechowało się bogactwem gatunkowym flory charakterystycznej dla wszystkich rodzajów siedlisk. Pod powierzchnią wody intensywnie rozwijały się zbiorowiska $\mathrm{z}$ rdestnicami (Potamogeton sp.), włosienicznikiem (Batrachium sp.), jezierzą morską i rogatkiem sztywnym. Najgłębsza część zbiornika zdominowana było przez łąki ramienicowe (Characeae). Licznie zidentyfikowane efipia rozwielitek (Daphnia) sugerują dobrze rozwinięty plankton pelagiczny. Okalająca jezioro strefa szuwaru miała charakter wielogatunkowy. Obok pałki wodnej obficie zaczęły występować m.in. turzyca nibyciborowata (Carex pseudocyperus), sadziec konopiasty (Eupatorium cannabinum), karbieniec pospolity (Lycopus europaeus), a później również cibora brunatna (Cyperus fuscus) i trzcina pospolita (Phragmites australis). Duża produkcja biomasy skutkowała stopniowym zarastaniem jeziora oraz zmianą charakteru osadu na, bogatą w materię organiczną, gytię detrytusową. Na obszarach podmokłych rozwijały się zbiorowiska z turzycami (Carex sp.), natomiast roślinność obszarów suchych zdominowana była przez nitrofilną pokrzywę zwyczajną (Urtica dioica), miętę nadwodną (Mentha aquatica), jaskra jadowitego (Ranunculus sceleratus) i szczaw polny (Rumex acetosella).

W tym czasie w otoczeniu zbiornika formowały się mezokratyczne lasy liściaste typu Quercetum mixtum. W zapisie pyłkowym z badanego stanowiska przełom okresu borealnego i atlantyckiego zaznaczył się gwałtownym i jednoczesnym wzrostem udziału wiązu, dębu oraz olszy. Taki układ krzywych może sugerować występowanie luki stratygraficznej.

W połowie okresu atlantyckiego zbiornik znajdował się w końcowej fazie zarastania. W miejscach bardziej wilgotnych silnie rozwinęły się grzybienie białe świadczące o wysokiej trofii wód. W zagłębieniu formowało się torfowisko, początkowo przy udziale turzyc, później znacząco wzrósł udział trzciny pospolitej. W takiej postaci torfowisko to funkcjonowało w okresie neoholocenu. Ukształtowany wtedy materiał miał postać żółtego torfu trzcinowego i mszysto-trzcinowego o słabym stopniu rozkładu. Brak wyraźnych zmian charakteru i składu osadu sugeruje stan stabilizacji torfowiska. Mimo to zaznacza się nieregularność przebiegu krzywych udziału pyłku drzew w diagramie pyłkowym, co może świadczyć o za- burzeniach bądź nieciągłościach w akumulacji torfu. Wyraźnym tego przykładem jest m.in. brak części krzywej graba pospolitego (Carpinus betulus). Niemożliwe zatem stało się precyzyjne rozdzielenie osadów deponowanych w okresie subborealnym i subatlantyckim.

W ostatnim etapie funkcjonowania torfowiska obok trzcin i turzyc pojawił się m.in. sit (Juncus sp.) i karbieniec pospolity. Oznaczono również oospory ramienic. Można zatem przypuszczać, że w tym czasie dno zagłębienia porastały wilgotne trzcinowiska urozmaicone niewielkimi przegłębieniami okresowo wypełnionymi wodą. Działalność człowieka zaznaczała się jedynie występowaniem roślin synantropijnych, tj. komosy (Chenopodium sp.) i dziurawca skrzydełkowanego (Hypericum tetrapterum). Nie stwierdzono natomiast makroszczątków roślin uprawnych. Wzbogacenie powierzchniowej warstwy w materię mineralną jest wynikiem postępującego procesu murszenia.

\section{Podsumowanie}

Wyniki analiz paleoekologicznych pozwoliły na wyodrębnienie dwóch głównych etapów rozwoju zbiornika. Pierwszy, jeziorny, obejmował kilka następujących po sobie faz będących wynikiem ewolucji zbiornika. Początkowo miał on charakter późnoglacjalnego jeziora oligotroficznego. Wraz z postępującym ociepleniem u progu holocenu następował rozwój makrofitów, którego kulminacyjny moment przypadł na przełom okresu borealnego i atlantyckiego. Funkcjonujące wówczas jezioro miało złożony charakter i cechowało się bogatą szatą roślinną, zarówno w strefie litoralnej, jak i pelagicznej. Ostatnia z faz jeziornych, przypadająca na okres atlantycki, charakteryzowała się silnym zarastaniem zbiornika i doprowadziła do powstania torfowiska. Na podstawie składu gatunkowego osadu stwierdzić można, że etap torfowiskowy był stosunkowo jednolity i nie ulegał znacznym zmianom na przestrzeni okresu subborealnego i subatlantyckiego.

Określenie początku sedymentacji jeziornej w analizowanym zagłębieniu wytopiskowym, usytuowanym w obrębie terasy V doliny Wisły, na młodszą część allerødu potwierdza czas kształtowania się niższych teras w okresie schyłku późnego glacjału. Wisła już na początku holocenu osiągnęła poziom współczesnego dna doliny, co znajduje potwierdzenie w badaniach dolnych odcinków dopływów Wisły na tym obszarze (Andrzejewski 1994).

Uzyskane wyniki sugerują konieczność kontynuacji badań, w tym także datowań radiowęglowych, w celu dokładniejszego ustalenia czasu istotnych przemian środowiska oraz rozpoznania ewentualnych przerw w akumulacji osadu. Istotnym problemem jest również określenie charakteru i wielkości zmian wywołanych działalnością człowieka, które szczególnie w południowej części torfowiska wydają się znaczące. 


\section{Literatura}

Andrzejewski L., 1994. Ewolucja system fluwialnego doliny dolnej Wisły w późnym vistulianie i holocenie na podstawie wybranych dolin jej dopływów. Rozprawy UMK, Toruń.

Bengston L., Ennel M., 1986. Chemical analysis. W: B.E. Berglund (red.), Handbook of Holocene Paleoecology and Paleohydrology. John Wiley \& Sons Ltd, Chichester: 423-451.

Hulisz P., Karasiewicz M.T., Dąbrowski M., Michalski A., Rauchflejsz M., 2012. Metody badań fizykochemicznych i chemicznych osadów zagłębienia w rezerwacie Retno. W: M.T. Karasiewicz, P. Hulisz, M. Świtoniak (red.), Postglacjalna historia zagłębienia bezodpływowego w rezerwacie Retno (Pojezierze Brodnickie). Wyd. Nauk. UMK, Toruń.

Kondracki J., 1998. Geografia regionalna Polski. PWN, Warszawa.

Kupryjanowicz M., Jurochnik A., 2009. Zapis pyłkowy postglacjalnych zmian roślinności zawarty w osadach dennych Jeziora Wigry. W: J. Rutkowski, L. Krzysztofiak (red.), Jezioro Wigry. Historia jeziora w świetle badań geologicznych i paleoekologicznych. Stowarzyszenie ,Człowiek i Przyroda”, Suwałki: 186-190.

Latałowa M., 2003. Późny vistulian. W: S. Dybova-Jachowicz, A. Sadowska (red.), Palinologia. Wyd. IB PAN, Kraków: 266-292.

Lindner L., 1992a. Holocen. W: L. Lindner (red.), Czwartorzęd. Osady, metody badań, stratygrafia. Wyd. PAE, Warszawa: 613-633.

Lindner L., 1992b. Plejstocen. W: L. Lindner (red.), Czwartorzęd. Osady, metody badań, stratygrafia. Wyd. PAE, Warszawa: 466-613.

Mangerud J., Andersen S.T., Berglund B.E., Donner J.J., 1974. Quaternary stratigraphy of Norden, a proposal for terminology and classification. Boreas 3: 109-128.
Markowski S., 1980. Struktura i właściwości podtorfowych osadów jeziornych rozprzestrzenionych na Pomorzu Zachodnim jako podstawa ich rozpoznania i klasyfikacji. W: Kreda jeziorna i gytia. Polskie Towarzystwo Przyjaciół Nauk o Ziemi, Gorzów Wielkopolski-Zielona Góra: 44-55.

Niewiarowski W., Weckwerth P., 2006. Geneza i rozwój rzeźby terenu. W: L. Andrzejewski, P. Weckwerth, S. Burak (red.), Toruń i jego okolice. Monografia przyrodnicza. Wyd. Nauk. UMK, Toruń: 65-93.

Podbielkowski Z., Tomaszewicz H., 1996. Zarys hydrobotaniki. Wyd. Nauk. PWN, Warszawa.

Ralska-Jasiewiczowa M., 1966. Osady denne Jeziora Mikołajskiego na Pojezierzu Mazurskim w świetle badań paleobotanicznych. Acta Palaeobotanica 7(2): 43-72.

Sadowska A., Chłopek K., 2003. Metodyka badań. Metody terenowe i laboratoryjne. W: S. Dybova-Jachowicz, A. Sadowska (red.), Palinologia. Wyd. IB PAN, Kraków: 73-79.

Tobolski K., 2000. Przewodnik do oznaczania torfów i osadów jeziornych. PWN, Warszawa.

Tomczak A., 1987. Evolution of the Vistula valley in the Torun Basin in the Late Glacial and Holocene. W: L. Starkel (red.), Evolution of the Vistula river valley during the last 15000 years. T. 2. Geographical Studies, Special Issue 1: 207-231.

Velichkevich F.U., Zastawniak E., 2006. Atlas of Plejstocene vascular plant macrofossils of Central and Eastern Europe. Pt. 1. Pteridophytes and monocotyledons, Wyd. IB PAN, Kraków: 7-12.

Walanus A., Nalepka D., 1996. Program POLPAL - palinologiczna baza danych. Instrukcja obsługi (1994). Wyd. IB PAN, Kraków.

Więckowski K., 1989. A new method of coring in deep lakes with rodoperated Samplers. Boreas 18(4): 357-358. 